medRxiv preprint doi: https://doi.org/10.1101/2021.08.19.21262307; this version posted August 24, 2021. The copyright holder for this preprint (which was not certified by peer review) is the author/funder, who has granted medRxiv a license to display the preprint in perpetuity. It is made available under a CC-BY-NC-ND 4.0 International license.

Evolution of virus

Bell

1

2

3

4

5

\title{
Evolutionary dynamics of a virus in a vaccinated population
}

Graham Bell

8

9

10

Biology Department and Redpath Museum

11 McGill University

12 Montreal, Quebec H3A 1B1, Canada

13

14 Email: graham.bell@mcgill.ca

15 
medRxiv preprint doi: https://doi.org/10.1101/2021.08.19.21262307; this version posted August 24, 2021. The copyright holder for this preprint (which was not certified by peer review) is the author/funder, who has granted medRxiv a license to display the preprint in perpetuity. It is made available under a CC-BY-NC-ND 4.0 International license.

Evolution of virus

Bell

16

17 The progress of an epidemic in a small closed community is simulated by an agent-based model

18

19

20

21

22

23

24 revaccination, using the prevalent strain to design the vaccine.

Summary

which allows vaccination and variation. The attributes of the virus are governed by two genetic loci: the P-locus, which determines growth, and the M-locus, which determines immune characteristics. Mutation at either locus modifies the attributes of the virus and leads to evolution through natural selection. For both loci the crucial variable is the potential mutation supply $U_{\text {Pot, }}$ because evolution is likely to happen when $U_{\text {Pot }}>1$. Mutation at the P-locus causes a limited increase in virulence, which may be affected by vaccine design. Mutation at the Mlocus may cause a qualitative shift of dynamic regime from a simple limited epidemic to a perennial endemic disease by giving rise to escape mutants which may themselves mutate. A broad vaccine that remains efficacious despite several mutations at the M-locus prevents this shift and provides protection despite the evolution of the virus. Escape variants may nevertheless arise through recombination after coinfection, and can be suppressed by timely 
medRxiv preprint doi: https://doi.org/10.1101/2021.08.19.21262307; this version posted August 24, 2021. The copyright holder for this preprint (which was not certified by peer review) is the author/funder, who has granted medRxiv a license to display the preprint in perpetuity.

It is made available under a CC-BY-NC-ND 4.0 International license .

Evolution of virus

Bell

\section{Introduction}

Once a virus has first infected a single individual in a population of susceptible hosts, its lineage may subsequently follow one of two paths: either it fails to be transmitted and soon becomes extinct, or it proliferates so as to cause an epidemic. Which path is followed depends in part on deterministic factors, such as its initial rate of transmission, and in part on stochastic factors, because the initial survival and transmission of the virus are strongly influenced by chance. The time course of an epidemic in a local population can be adequately described by the mathematical theory that has been developed over the last century (reviewed by Brauer 2017). If the virus is liable to vary when it replicates, however, the virus population will evolve during

41 the epidemic and as its properties change its dynamics may become more complicated (Lenski

42 \& May 1994, Day \& Proulx 2004, Day \& Gandon 2007), as in the well-known case of influenza

43 (reviewed by Nelson \& Holmes 2007). As for the virus population as a whole, the spread of any new strain, beginning with a single individual arising by mutation or recombination, will be

45 influenced both by deterministic processes such as natural selection and by stochastic has made the public more aware of virus evolution and more fearful of its consequences, as the spread of new strains undermines efforts to control the outbreak (Day et al. 2021). 
medRxiv preprint doi: https://doi.org/10.1101/2021.08.19.21262307; this version posted August 24, 2021. The copyright holder for this preprint (which was not certified by peer review) is the author/funder, who has granted medRxiv a license to display the preprint in perpetuity.

It is made available under a CC-BY-NC-ND 4.0 International license .

Evolution of virus

Bell

52 virus. The first kind, often called virulence or life-history variants, alters the extent of

53 proliferation within the host, which results in a viral titre characteristic of a particular strain.

54 This in turn affects its virulence, because a higher titre causes more severe symptoms and

55 endangers the host, and its transmissibility, because a higher titre results in more virus particles

56 being shed (May \& Anderson 1983, van Baalen \& Sabelis 1995). The second kind, often called

57 escape variants, alters the antigenic properties of the virus and may thereby enable it to evade

58 the immune system of the host (Gog \& Grenfell 2002, Grenfell et al. 2004, Fryer \& McLean

59 2011). These two approaches use different methods and have remained largely separate. The

60

evolution of virulence is usually viewed as a long-term process using quantitative population

61 genetics to model competition between many virus lineages, whereas escape is usually

62 represented as the short-term outcome of competition between two clones of virus (Gandon \&

63 Day 2007).

64 Vaccination protects the population by arming individuals with an immune response against

65 virus strains which have an antigenic profile similar to the vaccine. It is an effective method of

66 reducing the incidence of the disease, and may even drive the virus extinct if the frequency of

67 unvaccinated hosts is too low to sustain an epidemic (Anderson \& May 1991). It is also a

68

profound alteration of the host environment, however, and may thereby act as an agent of

69 selection on the virus population. Moreover, vaccinated individuals are not necessarily

70 equivalent to recovered individuals, either in terms of their immune response or the virulence

71 and transmissibility of any infection which succeeds in taking hold. When there are many

72 strains of virus circulating in a vaccinated population, each differing in its virulence,

73 transmissibility and antigenic properties, and each subject to stochastic as well as deterministic 
medRxiv preprint doi: https://doi.org/10.1101/2021.08.19.21262307; this version posted August 24, 2021. The copyright holder for this preprint (which was not certified by peer review) is the author/funder, who has granted medRxiv a license to display the preprint in perpetuity.

It is made available under a CC-BY-NC-ND 4.0 International license .

Evolution of virus

Bell

74

75

76

77

78

79

80

81

82

83

84

85

86

87

change, then analytical solutions of conventional mathematical models based on differential equations may be difficult to find (although Day et al. 2020 show how a complex situation can be analysed). Numerical solutions can still be found, of course, but agent-based simulations can be used instead (e.g. Roche, Drake \& Rohani 2011). These can incorporate any number of parameters with ease, at the expense of making it difficult to explore the parameter space thoroughly and correspondingly difficult either to identify or to validate general principles. The most radical approach is to abandon equations altogether, in favour of a set of rules that govern how individuals move around, meet one another, and infect others or are themselves infected. In this report I shall use an agent-based model based on rules rather than equations to describe the evolutionary dynamics of a virus in a vaccinated population. The virus resembles SARS-CoV-2 in some respects, but the model is intended only to suggest some general features of virus evolution, rather than to predict the future course of the pandemic.

This report is based on an agent-based, quasi-realistic model of an epidemic in an imaginary small town described in a previous report (Bell 2020). The program itself and a detailed account of the model are included in the Supplementary Material.

Variation and mutation. The virus has two loci that govern its interaction with a host. The Phenotype or P-locus governs the proliferation of the virus within the host, and thereby its virulence and transmissibility. The Immunity or M-locus governs the interaction of the virus with the immune system of the host. The ancestral strain responsible for the outbreak has 
medRxiv preprint doi: https://doi.org/10.1101/2021.08.19.21262307; this version posted August 24, 2021. The copyright holder for this preprint (which was not certified by peer review) is the author/funder, who has granted medRxiv a license to display the preprint in perpetuity.

It is made available under a CC-BY-NC-ND 4.0 International license .

Evolution of virus

Bell

95

96

97

98

99

100

101

102

103

104 105 host.

106

107

108

109

110

111

112

113

114

given states at the P-locus and the M-locus that determine its transmissibility, virulence and immune characteristics.

Each locus consists of a string of given length of binary digits ('bits'), one of which is switched from one state to the other when mutation occurs. Competition within the host is neglected, for simplicity, so that only successful mutations are considered - those that both arise and become fixed within an infected host, which then transmits the mutant strain. The effect of a mutation at the P-locus is to increase viral titre by a random factor from the value in the ancestral strain towards some fixed maximal value, leading to an increase, by a different random amount, in both transmissibility and virulence. A mutation at the M-locus alters the antigenic properties of the virus and may thereby enable it to evade the immune system of the

The number of mutations at either locus is limited by the number of times that the virus is transmitted, which for the ancestral strain is at most equal to the size of the host population. We can then define the potential mutation supply for either locus as $U_{\text {Pot }}=H u L$, where $H$ is the number of individuals in the host population, $u$ is the fundamental rate of mutation per site, and $L$ is the number of mutable sites at the locus. In an unvaccinated population, at least one mutation will arise, on average, if $U_{\text {pot }}>1$. Mutation and the initial spread of a mutant strain are stochastic events, however, so no mutation may occur, or, if it does, the new strain may soon become extinct. In a vaccinated population the condition is more stringent because a successful mutant must arise before the host population is fully vaccinated. 
medRxiv preprint doi: https://doi.org/10.1101/2021.08.19.21262307; this version posted August 24, 2021. The copyright holder for this preprint (which was not certified by peer review) is the author/funder, who has granted medRxiv a license to display the preprint in perpetuity. It is made available under a CC-BY-NC-ND 4.0 International license .

Evolution of virus

Bell

115

116

117

118

119

120

121

122

124

125

126

127

128

129

Immune response. In response to infection by a strain of virus with a given epitope sequence at its M-locus, the host generates an antibody with the complementary sequence and stores this in its immune memory. (For example, if the virus M-locus is 001011001, the host generates and stores 110100110.) If the host survives and is subsequently exposed to the same strain of virus, it is able to express the stored sequence and may thereby disable the virus. The effectiveness of the immune response depends on how the clearance of the virus is related to the degree of complementarity. The simplest mechanism is always to activate the immune response if complementarity equals or exceeds some threshold value, or alternatively the probability of activation might decrease continuously as some function of decreasing complementarity.

Vaccination. In vaccinated hosts, the sequence complementary to the vaccine sequence is likewise stored in immune memory. Vaccination is akin to previous infection by a virus whose sequence at the M-locus corresponds to the vaccine. It will thereby confer some degree of immunity to this strain of the virus: complete immunity for a highly efficacious vaccine, but only partial immunity for a low-efficacy vaccine. If the host is exposed to a strain of virus whose Mlocus does not correspond exactly with the vaccine, its immunity will be less, to an extent that depends on the specificity of the vaccine. A narrow vaccine will activate the immune response, but only if it is fully complementary to an invading virus; a broad vaccine may be less effective against a fully complementary virus, but might be active to some extent against a strain with partial complementarity.

If an individual becomes infected by the virus despite vaccination or previous infection, the virus population within the host will grow, as it does in naïve hosts. It may grow to a different titre in naïve, recovered and vaccinated individuals, however, so that its virulence and 
medRxiv preprint doi: https://doi.org/10.1101/2021.08.19.21262307; this version posted August 24, 2021. The copyright holder for this preprint (which was not certified by peer review) is the author/funder, who has granted medRxiv a license to display the preprint in perpetuity.

It is made available under a CC-BY-NC-ND 4.0 International license .

Evolution of virus

Bell

137 transmissibility will in general differ between these categories of host. A weak vaccine permits

138 a higher titre and thereby greater virulence and transmissibility, whereas a strong vaccine

139 suppresses the growth of the virus and reduces both virulence and transmissibility, relative to

140 naïve unvaccinated individuals.

141 Standard parameter set. The simulations reported here were conducted in a small town of

142 about 4000 people with a demographic and occupational profile similar to that of many

143 communities in Europe and North America. The parameters for the simulations reported here

144 were chosen so that an epidemic infects about $75-80 \%$ of an unvaccinated population over a

145 period of about 100 days before the virus is no longer able to propagate and becomes locally

146 extinct. The authorities may take measures to control, curtail or delay the epidemic, including

147 vaccination. A vaccination program proceeds as a specified series of cohorts identified by age

148 and occupation. In the simulations reported here, vaccination gives permanent protection and

149 all individuals are vaccinated during the program, regardless of infection history and current

150 status, although the model allows incomplete compliance and temporary immunity.

Results and Discussion

154 Weak and strong vaccines. The effects of mutation at the P-locus on virulence and

155 transmissibility are antagonistic, because hosts infected by a mutant strain with increased

156 virulence are more likely to die and thus unable to transmit the virus. The spread of a mutant

157 strain is therefore governed by the balance of positive and negative effects on the rate of 
medRxiv preprint doi: https://doi.org/10.1101/2021.08.19.21262307; this version posted August 24, 2021. The copyright holder for this preprint (which was not certified by peer review) is the author/funder, who has granted medRxiv a license to display the preprint in perpetuity.

It is made available under a CC-BY-NC-ND 4.0 International license .

Evolution of virus

Bell

158

159

160

161

162

163

164

165

166

167

168

169

170

171

172

173

174

175

176

177

178

179

transmission, which is expected to lead to an optimal intermediate level of virulence (Anderson

\& May 1982). This balance may be shifted by vaccination. In particular, the cost of virulence arising from the excess death rate of infected hosts is reduced if the virus is able to grow slowly in vaccinated hosts, so that selection will favour increased growth and hence increased virulence. This possibility has led to the controversial conclusion that a weak vaccine may actually favour the spread of more virulent strains of the virus (Gandon et al. 2001; Gandon et al. 2003).

The simplest model is to suppose that naïve hosts are completely susceptible and recovered hosts are completely immune, whereas vaccinated hosts have an intermediate level of immunity. The virulence of the ancestral strain of virus in those vaccinated hosts which become infected is likewise intermediate between its value in naive and recovered hosts. We then expect that greater virulence will evolve in vaccinated hosts, and consequently that virulence in naïve hosts will increase as a correlated response to selection. As mutations at the P-locus arise and spread by virtue of their increased transmissibility, the mean virulence of the virus, over all infected hosts, will tend to increase. The maximum value of mean virulence during the epidemic is shown in Figure 1 for replicate populations with different vaccination states. A weak vaccine does induce the evolution of somewhat greater virulence in naïve hosts, relative to a strong vaccine, but the difference between weak and strong vaccines is not formally significant $(F=3.4 ; d f=1,38 ; 0.1>P>0.05)$, and virulence is greatest in unvaccinated populations because of their greater mutation supply. Selection for increased virulence is expected to be slight, because individuals who die have already had the opportunity to transmit the virus (Day et al. 2020). It is also highly variable because it depends on two stochastic 
medRxiv preprint doi: https://doi.org/10.1101/2021.08.19.21262307; this version posted August 24, 2021. The copyright holder for this preprint (which was not certified by peer review) is the author/funder, who has granted medRxiv a license to display the preprint in perpetuity.

It is made available under a CC-BY-NC-ND 4.0 International license .

Evolution of virus

Bell

180

181

182

183

184

185

186

187

188

189

190

191

192

193

194

195

196

197

198

199

200

201

factors: the effect of mutations on virulence and transmissibility, and their timing relative to the vaccination program. The incidence of cases with severe symptoms (which may result in death) is increased by mutation and reduced by vaccination, while the difference between weak and strong vaccines is imperceptible (Supplementary Figure 1).

Evolution of antigenic evasion. Without variation at the M-locus, vaccination using the ancestral strain as a model halts the epidemic and substantially reduces the number of cases, provided that it is efficacious, universally administered and timely. Even if these conditions are met, however, mutations at the M-locus may enable the virus to spread, provided they are sufficiently frequent. If $U_{\text {pot }}<1$ it is unlikely (but not impossible) that any mutations will occur, and vaccination will be effective. If $U_{\text {pot }}>1$ then escape mutations will usually (although not always) occur, and lineages bearing these mutations can spread even in a fully vaccinated population because they render the whole population susceptible: mutations of this sort create their own potential mutation supply, and may thereby give rise to an indefinite series of further mutations in the future. The succession of mutant strains can shift the population from one dynamic regime to another (Supplementary Figure 2). In the first place, a mutant strain may spread after the initial collapse of the epidemic, which will follow from vaccination or simply from the reduced availability of hosts who are susceptible to the ancestral strain. As the mutant strain in turn declines in abundance it can be replaced by a third mutant strain, if one should occur, and in this way give rise to a more or less regular succession of disease cycles. Alternatively, if $U_{\text {Pot }}$ > 1 mutant strains might arise so frequently that several will be circulating at any given time, and the virus might be maintained for a long period of time with irregular low-amplitude fluctuations over time, before eventually becoming stochastically extinct. Figure 
medRxiv preprint doi: https://doi.org/10.1101/2021.08.19.21262307; this version posted August 24, 2021. The copyright holder for this preprint (which was not certified by peer review) is the author/funder, who has granted medRxiv a license to display the preprint in perpetuity.

It is made available under a CC-BY-NC-ND 4.0 International license .

Evolution of virus

Bell

202

203

204

205

206

207

208

209

210

211

212

213

214

215

216

217

218

219

220

221

222

223

2 shows that the shift from a short-term regular epidemic to a longer-term evolving epidemic in a vaccinated population occurs around the critical potential mutation supply of $U_{\text {pot }} \approx 1$. The shift from one dynamic regime to another is thus governed by the potential mutation supply.

No such shift will occur in an unvaccinated population, because escape mutations will spread only in recovered individuals. Most of these will appear relatively early in the epidemic (because the rate of transmission and thus the opportunity for mutation is greatest at this time), before many host individuals have recovered from the infection and are immune to the ancestral strain. Consequently, the density of susceptible hosts is not much greater for a mutant and its selective advantage is only modest, so the lineage will spread only slowly and is likely to die out. In a vaccinated population, on the other hand, the transmission of the ancestral strain is blocked by the vaccine, the selective advantage of mutants is correspondingly much greater, and a mutant lineage can rapidly expand to fill the ecological space provided by vaccinated but susceptible hosts. The potential for vaccination-driven emergence of a vaccineresistant strain was demonstrated analytically by Scherer \& McLean (2002).

The outcome of selection in a vaccinated population will often be a shift in dynamic regime and a substantial increase in the number of cases, relative to a comparable unvaccinated population, because some host individuals will be infected twice, once by the ancestral strain and again by the mutant. If several mutations occur sequentially, each will be likely to spread as its predecessor declines, so that many individuals are infected several times and the total number of cases greatly exceeds that of an unvaccinated population. The effect of vaccination on the total number of cases when there is recurrent mutation at the M-locus is illustrated in Figure 3. In some examples, where no mutation occurs until late in the vaccination program, or 
medRxiv preprint doi: https://doi.org/10.1101/2021.08.19.21262307; this version posted August 24, 2021. The copyright holder for this preprint (which was not certified by peer review) is the author/funder, who has granted medRxiv a license to display the preprint in perpetuity.

It is made available under a CC-BY-NC-ND 4.0 International license .

Evolution of virus

Bell

224 fails to spread if it occurs earlier, the resurgence of the epidemic does not occur and

225 vaccination reduces the overall number of infections. In most cases, however, recurrent

226 mutation with $U_{\text {Pot }} \approx 1$ prolongs the epidemic and causes many more cases than would occur in

227 a comparable unvaccinated population, where the number of cases is limited by the number of

228 host individuals, provided that infection confers immunity in recovered individuals. This

229 surprising result follows from the greater selective advantage of strains which carry a mutation

230 at the M-locus in a vaccinated population.

231 Narrow and broad vaccines. A narrow vaccine is highly specific, being efficacious against the

232 ancestral strain of virus but giving little protection against antigenic variants. A broad vaccine is

233 less active against the ancestral strain, but provides some protection against variants, even

234 when complementarity is incomplete. The perfect vaccine would be efficacious against both

235 the ancestral strain and mutational variants, but efficacy and breadth might be incompatible.

236 Suppose that the efficacy E of a vaccine, the probability that it confers immunity to a given

237 strain of virus, declines exponentially with decreasing complementarity $\mathrm{C}$, such that $\mathrm{E}_{\mathrm{C}}=\mathrm{E}_{\text {limit }}$

$238 \exp \left[-k\left(C_{\text {limit }}-C\right)\right]$, where $E_{\text {limit }}$ is the efficacy of the vaccine when it corresponds perfectly with

239 the M-locus of the strain $\left(C=C_{\text {limit }}\right)$. A broad vaccine would then have a shallow slope (small $\left.\mathrm{k}\right)$,

240 giving greater protection against similar strains at the expense of giving less protection against

241 matching strains (low $E_{\text {limit }}$ ). Hence, a broad vaccine might reduce the selective advantage of

242 mutations at the M-locus, and thereby prevent the epidemic from becoming cyclical or

243 perpetual; for example, Fryer \& McLean (2011) suggested that broad vaccines against HIV

244 might suppress the emergence of escape mutants. This idea was investigated by manipulating

245 Elimit and $k$ to produce narrow, medium and broad vaccines in populations where mutation at 
medRxiv preprint doi: https://doi.org/10.1101/2021.08.19.21262307; this version posted August 24, 2021. The copyright holder for this preprint (which was not certified by peer review) is the author/funder, who has granted medRxiv a license to display the preprint in perpetuity. It is made available under a CC-BY-NC-ND 4.0 International license .

Evolution of virus

Bell

246

247

248

249

250

251

252

253

254

255

256

257

258

259

260

261

262

263

264

265

266

267

the M-locus (but not the P-locus) was allowed. The outcome showed little effect of vaccine design, but an overwhelming effect of mutation supply. In unvaccinated populations the epidemic was limited, as before (Figure 4). Vaccinated populations behaved in the same way, provided that few mutations occurred, since most mutations fail to spread. Above a certain threshold, however, escape mutations shifted the population into a new regime with multiple infections per host individual and far more cases overall. A narrow vaccine may predispose the population to shift, but the effect is modest at best $\left(X^{2}=3.0, d f=1,0.1>P>0.05\right)$, whereas the effect of mutation supply is clear.

Paradox of vaccination. Simple escape mutations at the M-locus not only prolong the epidemic and increase the number of cases, but may shift the dynamic regime from a limited short-term epidemic to a perennial endemic disease. This outcome is not borne out by empirical data on the effects of vaccination. Most vaccines remain effective for long periods of time, and in many cases (e.g. measles) resistance has never evolved. The rarity of vaccine resistance is particularly striking in contrast with the rapid evolution of resistance to antibiotics (Mishra et al. 2012).

This may be a consequence of mutation supply within the host: the immune reaction clears an infection when the pathogen population is still small, whereas antibiotics are usually administered only when the pathogen population has become large enough to cause overt symptoms (Kennedy \& Read 2017, 2018; Bell \& MacLean 2018). Nevertheless, escape variants have been reported for some vaccines, for example hepatitis B. Even in this case, however, they have failed to eliminate the ancestral strain, perhaps because of a high cost of resistance (Francois et al. 2001). Resistance might often be costly because viral genomes are very 
medRxiv preprint doi: https://doi.org/10.1101/2021.08.19.21262307; this version posted August 24, 2021. The copyright holder for this preprint (which was not certified by peer review) is the author/funder, who has granted medRxiv a license to display the preprint in perpetuity.

It is made available under a CC-BY-NC-ND 4.0 International license .

Evolution of virus

Bell

268

269

270

271

272

273

274

275

276

277

278

279

280

281

282

283

284

285

286

287

288

289

compact and hence likely to be disrupted by random change. Reid et al. (2019) reviewed a wide range of models designed to predict the consequences of vaccination against an evolving pathogen, most of which referred to a specific vaccine against a particular pathogen. They concluded that: "Overall, the studies of vaccines that have been in use, have trial data, or have existing homologs predicted positive health outcomes despite vaccine resistance." The few exceptions require conditions which are thought to be exceptional, such as high levels of crossimmunity between contemporary strains (e.g. Worby et al. 2017). Hence, real-world studies overwhelmingly predict that vaccination will be beneficial, even in the long term against an evolving pathogen.

Vaccine resistance is expected to be rare if the potential mutation supply is usually very low.

The rate of mutation per base pair per replication is much higher In RNA viruses than in organisms with a DNA genome, so the requirement that the potential mutation supply be small might seem unlikely. However, the second reason given by Kennedy \& Read (2017) for the rarity of vaccine resistance is the extensive redundancy of most vaccines: a variety of antibodies can be produced by the host in response to the presentation of several epitopes on each of several antigens by the pathogen. Consequently, an effective immune response can be mounted against strains similar to, but not identical with, the ancestral strain, leading to the broad cross-reactivity identified by McLean (1995) as a feature of successful vaccines. Most vaccines might therefore tend to be both broad and efficacious, however unlikely such a felicitous combination might seem. Consider a narrow vaccine, which is $100 \%$ efficacious against the exactly corresponding sequence at the M-locus of the virus, but otherwise completely inactive, so that a single mutation confers immunity. If the vaccine were somewhat 
medRxiv preprint doi: https://doi.org/10.1101/2021.08.19.21262307; this version posted August 24, 2021. The copyright holder for this preprint (which was not certified by peer review) is the author/funder, who has granted medRxiv a license to display the preprint in perpetuity.

It is made available under a CC-BY-NC-ND 4.0 International license .

Evolution of virus

Bell

290

291

292

293

294

295

296

297

298

299

300

301

302

303

304

305

306

307

308

309

310

broader, so that it also gave $100 \%$ protection against strains that differed at any one of the sites of the M-locus, then a double mutation would be required for immunity. The potential mutation supply now refers to the supply of double mutants, which will be proportional to $\mathrm{u}^{2}$. The vaccine now restricts the spread of the virus to a single epidemic, and no shift of dynamic regime occurs (Figure 5). This does not require perfect efficacy. If the vaccine is only $70 \%$ efficacious, the number of cases is usually increased only slightly, relative to a perfectly efficacious vaccine. On rare occasions, however, a mutation may occur early in the epidemic and drift to high frequency, such that the mutant lineage is liable to undergo a second mutation before the (rather ineffective) vaccination program has eliminated the virus; it is only in this case that a shift in dynamic regime will occur.

Revaccination. If mutation at the $\mathrm{M}$-locus is generating escape mutants, revaccination might halt the spread of a mutant strain, using the most abundant contemporary strain itself as the model for the vaccine. In an unvaccinated population the epidemic will take its normal course, and die out when the virus is no longer able to proliferate. If a single mutation appears before a vaccination program is fully implemented the ancestral strain is eliminated by the vaccine, producing a fall in the number of new cases, but the mutant strain then spreads rapidly. The outcome is an increase in the total number of cases, as previously noted. Revaccination against the most abundant contemporary strain usually palliates this trend, although it is only effective if administered swiftly (Supplementary Figure 3). Revaccination can reduce the number of excess cases if it is administered soon after the previous vaccination program but if it is delayed its effect is less because the mutant strain has already reached high frequency (Figure 3 ). 
medRxiv preprint doi: https://doi.org/10.1101/2021.08.19.21262307; this version posted August 24, 2021. The copyright holder for this preprint (which was not certified by peer review) is the author/funder, who has granted medRxiv a license to display the preprint in perpetuity.

It is made available under a CC-BY-NC-ND 4.0 International license .

Evolution of virus

Bell

311 Recombination. The selection of more highly transmissible variants arising by mutation at the

312 P-locus has only a modest effect on the dynamics of the epidemic, but might be more

313 consequential if they were linked with escape mutants at the M-locus. The probability of

314 stochastic loss of a novel mutation at the M-locus, for example, will be less if it has become

315 linked to a highly transmissible variant caused by mutation at the P-locus. Linkage might arise

316 in two ways: through sequential mutation, or through coinfection leading to intergenic

317 recombination. In principle, recombination is likely to be the more important if coinfection is

318 much more frequent than the rate of mutation per locus. To investigate this possibility,

319 populations with different combinations of mutation and recombination can be set up: neither

320

mutation nor recombination; mutation at the P-locus alone; mutation at the M-locus alone;

321 mutation at both loci without recombination; and mutation at both loci with recombination.

322 The outcome of the experiment is shown in Figure 6. The first three treatments yield results

323 similar to those already described. With neither mutation nor recombination, the epidemic

324 follows a normal course, infecting a substantial proportion of the population before being

325 knocked down by vaccination and then dying out; mutations at the P-locus which increase

326 virulence and transmissibility cause a modest rise in the number of cases, whereas mutations at

327 the M-locus may lead to a new dynamic regime in which the virus evolves to evade the vaccine,

328 many individuals are infected several times and the total number of cases exceeds the

329 population size. When there is mutation at both loci, but no coinfection, linkage must come

330 about as the consequence of a mutation in one locus occurring in a lineage which already bears

331 a mutation at the other. This causes a modest increase in the average number of cases over

332 the course of the epidemic, relative to a population in which mutation occurs only at the M- 
medRxiv preprint doi: https://doi.org/10.1101/2021.08.19.21262307; this version posted August 24, 2021. The copyright holder for this preprint (which was not certified by peer review) is the author/funder, who has granted medRxiv a license to display the preprint in perpetuity.

It is made available under a CC-BY-NC-ND 4.0 International license .

Evolution of virus

Bell

333 locus. If coinfection is permitted, linkage may arise either by sequential mutation or by

334 recombination. This causes a further increase in the average number of cases, suggesting an

335 effect of recombination in addition to the effect of sequential mutation alone. The marginal

336 (additional) effects of mutation and recombination can then be calculated from the five

337 treatment combinations:

No mutation or recombination

Phe- Imm- Rec-

scaled to 1

339

Phe+ Imm- Rec-

Mutation at M-locus only

Phe- Imm+ Rec-

4.38

343

344

These marginal effects largely depend on whether the dynamic regime is changed by the treatment rather than a smooth increase in the average number of cases. The experiment

illustrates the overriding qualitative effect of escape mutations at the M-locus and the modest

347 but appreciable quantitative contribution of mutations at the P-locus, either alone or in combination with mutations at the M-locus. It is possible that the principal effect of recombination, when coinfection is much more frequent than successful mutation, is to facilitate the transition from a regular limited epidemic to a long-term endemic infestation.

\section{Conclusions}

352 Virus populations will evolve swiftly when there is genetic variation for immune characteristics

353 or within-host growth. The maximum quantity of variation is the potential mutation supply, 
medRxiv preprint doi: https://doi.org/10.1101/2021.08.19.21262307; this version posted August 24, 2021. The copyright holder for this preprint (which was not certified by peer review) is the author/funder, who has granted medRxiv a license to display the preprint in perpetuity.

It is made available under a CC-BY-NC-ND 4.0 International license .

Evolution of virus

Bell

354 which is the maximum number of mutations in a simple epidemic: $U_{\text {Pot }}=$ HuL. This suggests

that there is a threshold at about $U_{\text {pot }}=1$, above which mutations are likely to occur, leading to the evolution of the virus population. The simulations based on an agent-based model broadly

357 support the analytical results of previous theory.

358 Virulence tends to increase when $U_{\text {Pot }}>1$ for the P-locus, and this may be modulated by vaccine design. The total number of cases during the epidemic cannot exceed the number of host individuals, however, and will usually be substantially less. Any increase in morbidity will be

361 limited, especially when a vaccination program has been implemented.

362 Mutation at the M-locus may have a qualitatively different outcome. Escape mutations at the M-locus not only prolong the epidemic and increase the number of cases, but may shift the

364 dynamic regime from a limited short-term epidemic to a perennial endemic disease. Both 365 regimes are examples of evolutionary rescue, because a population that would otherwise 366 become extinct is perpetuated by natural selection through the spread of mutants each of

367 which has a positive rate of increase. Simulations confirm that a shift of dynamic regime is likely 368 to occur when the potential mutation supply $U_{\text {pot }}>1$. This is because each successful mutation 369 creates its own potential mutation supply and can generate as many new mutations as the 370 ancestral strain. If escape mutations which evade vaccines based on the ancestral virus become 371 established then the epidemic may be prolonged almost indefinitely, unless it can be halted by

372 prompt revaccination. A vaccine which is both broad and efficacious will prevent this shift 373 because only multiply-mutant or recombinant strains will evade the immune response, and it 374 seems likely that most vaccines have this combination of properties. 
medRxiv preprint doi: https://doi.org/10.1101/2021.08.19.21262307; this version posted August 24, 2021. The copyright holder for this preprint (which was not certified by peer review) is the author/funder, who has granted medRxiv a license to display the preprint in perpetuity.

It is made available under a CC-BY-NC-ND 4.0 International license .

Evolution of virus

Bell

375 The classic case of a pathogen that has repeatedly evolved vaccine resistance through mutation

376 and recombination is influenza A virus (reviewed by Taubenberger \& Kash 2010). SARS-Cov-2 is

377 also a single-stranded RNA virus, and it is possible that escape mutations will occur. The

378 evolution of SARS-Cov-2 up to February 2021 has been reviewed by Rochman et al. (2021).

379 Altmann, Boyton \& Beale (2021) have reviewed the evidence (to March 2021) that mutations

380 affecting the spike protein of SARS-Cov-2 cause changes in viral titre or immune recognition or

381 both. All the variants of concern involve several mutations in the spike protein and must have

382 arisen by sequential mutation or recombination or both. Several variants that have spread

383 recently are resistant to plasma from recovered or vaccinated individuals (Wang et al. 2021),

384 and deletions that cause some degree of resistance arise repeatedly in infected patients

385 (McCarthy et al. 2021). The crucial statistic is the frequency of reinfection, which is poorly

386 defined (but not vanishingly small) for SARS-Cov-2 (Boyton \& Altmann 2021).

387 Although deterministic processes such as mutation supply and natural selection can be

recognised, stochastic processes are also important and may be decisive. All the experiments

389 described in this report show a great deal of scatter, with extreme outliers in some cases and

qualitatively different outcomes in others, even when the initial state of the population, the

mutation rate and the vaccination schedule are identical. The small size of the host population

392 is responsible for some of this scatter, but the initial fate of a mutant is influenced by the small

size (initially a single individual) of the mutant lineage itself, independently of the overall size of

394 the population (see Day et al. 2020, Supplementary Material, equation S8), while the schedule

395 and phenotypic effects of mutations are intrinsically stochastic. In some cases, the effect of a

396 treatment (such as vaccination) or a condition (such as mutation) are quite clear, but in others 
medRxiv preprint doi: https://doi.org/10.1101/2021.08.19.21262307; this version posted August 24, 2021. The copyright holder for this preprint (which was not certified by peer review) is the author/funder, who has granted medRxiv a license to display the preprint in perpetuity. It is made available under a CC-BY-NC-ND 4.0 International license.

Evolution of virus

Bell

397 the outcome is dominated by stochastic processes and the consistent effect of an intervention

398 is difficult to discern. Day et al. (2020) make a similar point on the basis of an analytical

399 mathematical model.

400 More broadly, the dynamics of an epidemic, after the passage of the initial strain, are governed

401 by evolutionary processes involving variation and natural selection. In order to evaluate these

402 processes the most urgent preliminary task is to estimate the potential mutation supply for loci

403 which govern the immune properties and within-host growth of the virus. Practical

404 recommendations which do not include expert guidance on the potential for evolutionary

405 change during the course of an epidemic will be incomplete.

406

407 Acknowledgments. I am grateful for comments on an earlier version of this article by Austin

408 Burt and Craig MacLean. My research is supported by a Discovery Grant from the Natural

409 Sciences and Engineering Research Board of Canada (Grant RGPIN/6945-2013).

410

411 
medRxiv preprint doi: https://doi.org/10.1101/2021.08.19.21262307; this version posted August 24, 2021. The copyright holder for this preprint (which was not certified by peer review) is the author/funder, who has granted medRxiv a license to display the preprint in perpetuity.

It is made available under a CC-BY-NC-ND 4.0 International license .

Evolution of virus

Bell

413 Figure 1. Evolution of virulence in populations with mutation at the P-locus. Plots show the

414 maximum value during the epidemic of mean virulence in naïve (never infected) hosts, for 20

415 replicate populations with identical initial composition but different vaccination status. The

416 upper limit of variation is set at $3 x$ the initial level of virulence. The values of virulence an

417 Figure 2. Dynamics of vaccinated populations with different rates of mutation at the M-locus. E

418 denotes a regular single epidemic; R recurrent cyclical epidemics; Q long-term infestation without clear

419 cyclical structure. The $x$-axis is the potential mutation supply $U_{\text {pot }}$ per locus, with the vertical line

420 showing $\mathrm{U}_{\mathrm{Pot}} \approx 1$ as an average for a vaccinated population in which no mutations occur. The horizontal

421 broken line is the population size. The plot shows 6 replicate populations at each of 10 mutation rates;

422 points have been jiggled slightly for clarity.

423 Figure 3. Effect of vaccination and revaccination on the number of cases under recurrent

424 mutation at the M-locus. Treatments for each of 20 replicate populations have identical initial

425 state; different replicates have same parameter values but different initial states. Ranked by

426 number of cases in the vaccinated population. Vaccination beginning 6 weeks after inoculation,

427 in three cohorts spaced by 3 weeks each; revaccination occurs 10 weeks (short lag) or 16 weeks

428 (long lag) after initial vaccination.

429 Figure 4. The effect of vaccine design and mutation supply on the number of cases during an

430 epidemic. The plot shows 20 independent replicate populations for each treatment. The $\mathrm{x}$-axis

431 shows all mutations, whether or not they spread. 
medRxiv preprint doi: https://doi.org/10.1101/2021.08.19.21262307; this version posted August 24, 2021. The copyright holder for this preprint (which was not certified by peer review) is the author/funder, who has granted medRxiv a license to display the preprint in perpetuity.

It is made available under a CC-BY-NC-ND 4.0 International license .

Evolution of virus

Bell

432 Figure 5. Effect of a broad efficacious vaccine. Individuals are supposed to be immune only if

433 the vaccine is completely complementary to the strain they are exposed to, so that a single

434 mutation at the I-locus of the virus suffices for infection, or that they are immune if the vaccine

435 differs by no more than one site from the strain they are exposed to, so that a double mutation

436 at the M-locus of the virus is required for infection. The values plotted are the total number of

437 cases during the epidemic, for pairs of populations (20 replicate pairs) with identical initial

438 state. Solid circles refer to a vaccine with $100 \%$ efficacy, open triangles with $70 \%$ efficacy. The

439 solid line is the line of equality. The dashed line marks the approximate population size of 4000

440 individuals.

441 Figure 6. The effect of mutation and recombination on the total number of infections during an

442 epidemic in a vaccinated population. Mutation either occurs or not at the P-locus (with probability $2 \mathrm{x}$

$44310^{-4}$ per bit per replication) and the M-locus (with probability $8 \times 10^{-5}$ per bit per replication), and

444 recombination occurs after coinfection (with probability 0.01 per transmission) or not. Parameters other

445 than the occurrence of mutation or recombination have the same value in all runs. Each of the five

446 treatments has 20 independent replicates, ranked in order of increasing number of cases in each. 
medRxiv preprint doi: https://doi.org/10.1101/2021.08.19.21262307; this version posted August 24, 2021. The copyright holder for this preprint (which was not certified by peer review) is the author/funder, who has granted medRxiv a license to display the preprint in perpetuity. It is made available under a CC-BY-NC-ND 4.0 International license .

Evolution of virus

Bell

Altmann, D.M., Boyton, R.J. and Beale, R., 2021. Immunity to SARS-CoV-2 variants of

451

concern. Science, 371(6534), pp.1103-1104.

452

Anderson, R. M. \& May, R. M. 1982 Coevolution of hosts and parasites. Parasitology 85, 411-

453

426.

454 Anderson, R.M. and May, R.M., 1992. Infectious diseases of humans: dynamics and control.

455 Oxford University Press.

456 Bell, G. and MacLean, C., 2018. The search for 'evolution-proof'antibiotics. Trends in

457 Microbiology, 26(6), pp.471-483.

458 Benvenuto, D., Giovanetti, M., Ciccozzi, A., Spoto, S., Angeletti, S. and Ciccozzi, M., 2020. The

459 2019-new coronavirus epidemic: evidence for virus evolution. Journal of medical

460 virology, 92(4), pp.455-459.

461 Boyton, R.J. and Altmann, D.M., 2021. Risk of SARS-CoV-2 reinfection after natural

462 infection. The Lancet, 397(10280), pp.1161-1163.

463 Brauer, F., 2017. Mathematical epidemiology: Past, present, and future. Infectious Disease

464 Modelling, 2(2), pp.113-127.

465 Day, T. and Gandon, S., 2007. Applying population-genetic models in theoretical evolutionary 466 epidemiology. Ecology Letters, 10(10), pp.876-888.

467 Day, T., Gandon, S., Lion, S. and Otto, S.P., 2020. On the evolutionary epidemiology of SARS-

468 CoV-2. Current Biology, 30(15), pp.R849-R857. 
medRxiv preprint doi: https://doi.org/10.1101/2021.08.19.21262307; this version posted August 24, 2021. The copyright holder for this preprint (which was not certified by peer review) is the author/funder, who has granted medRxiv a license to display the preprint in perpetuity. It is made available under a CC-BY-NC-ND 4.0 International license .

Evolution of virus

Bell

Day, T. and Proulx, S.R., 2004. A general theory for the evolutionary dynamics of virulence. The American Naturalist, 163(4), pp.E40-E63.

471 François, G., Kew, M., Van Damme, P., Mphahlele, M.J. and Meheus, A., 2001. Mutant hepatitis

472 B viruses: a matter of academic interest only or a problem with far-reaching

473 implications?. Vaccine, 19(28-29), pp.3799-3815.

474 Fryer, H.R. and McLean, A.R., 2011. Modelling the spread of HIV immune escape mutants in a

475 vaccinated population. PLoS computational biology, 7(12), p.e1002289.

476 Gandon, S. and Day, T., 2007. The evolutionary epidemiology of vaccination. Journal of the

477 Royal Society Interface, 4(16), pp.803-817.

478 Gandon, S., Mackinnon, M. J., Nee, S. \& Read, A. F. 2001. Imperfect vaccines and the evolution

479 of pathogen virulence. Nature $414,751-756$.

480 Gandon, S., Mackinnon, M., Nee, S. \& Read, A.F. 2003. Imperfect vaccination: some

481 epidemiological and evolutionary consequences. Proceedings of the Royal Society of London B

$482 \quad 270: 1129-1136$.

483 Gog, J.R. and Grenfell, B.T., 2002. Dynamics and selection of many-strain pathogens.

484 Proceedings of the National Academy of Sciences, 99(26), pp.17209-17214.

485 Grenfell, B.T., Pybus, O.G., Gog, J.R., Wood, J.L., Daly, J.M., Mumford, J.A. and Holmes, E.C., 486 2004. Unifying the epidemiological and evolutionary dynamics of

487 pathogens. science, 303(5656), pp.327-332. 
medRxiv preprint doi: https://doi.org/10.1101/2021.08.19.21262307; this version posted August 24, 2021. The copyright holder for this preprint (which was not certified by peer review) is the author/funder, who has granted medRxiv a license to display the preprint in perpetuity. It is made available under a CC-BY-NC-ND 4.0 International license .

Evolution of virus

Bell

488 Kennedy, D.A. and Read, A.F., 2017. Why does drug resistance readily evolve but vaccine

489 resistance does not?. Proceedings of the Royal Society B: Biological Sciences, 284(1851),

$490 \quad$ p.20162562.

491 Kennedy, D.A. and Read, A.F., 2018. Why the evolution of vaccine resistance is less of a concern

492 than the evolution of drug resistance. Proceedings of the National Academy of

493 Sciences, 115(51), pp.12878-12886.

494 Lenski, R.E. and May, R.M., 1994. The evolution of virulence in parasites and pathogens:

495 reconciliation between two competing hypotheses. Journal of theoretical biology, 169(3),

496 pp.253-265.

497 May, R.M. and Anderson, R.M., 1983. Epidemiology and genetics in the coevolution of parasites

498 and hosts. Proceedings of the Royal society of London. Series B. Biological sciences, 219(1216),

499 pp.281-313.

500 McCarthy, K.R., Rennick, L.J., Nambulli, S., Robinson-McCarthy, L.R., Bain, W.G., Haidar, G. and

501 Duprex, W.P., 2021. Recurrent deletions in the SARS-CoV-2 spike glycoprotein drive antibody

502 escape. Science, 371(6534), pp.1139-1142.

503 McLean AR. 1995 Vaccination, evolution and changes in the efficacy of vaccines: a theoretical

504 framework. Proc. R. Soc. Lond. B 261, 389-393.

505 Mishra, R.P., Oviedo-Orta, E., Prachi, P., Rappuoli, R. and Bagnoli, F., 2012. Vaccines and

506 antibiotic resistance. Current opinion in microbiology, 15(5), pp.596-602. 
medRxiv preprint doi: https://doi.org/10.1101/2021.08.19.21262307; this version posted August 24, 2021. The copyright holder for this preprint (which was not certified by peer review) is the author/funder, who has granted medRxiv a license to display the preprint in perpetuity. It is made available under a CC-BY-NC-ND 4.0 International license .

Evolution of virus

Bell

507 Nelson, M.I. and Holmes, E.C., 2007. The evolution of epidemic influenza. Nature reviews

508 genetics, 8(3), pp.196-205.

509 Reid, M.C., Peebles, K., Stansfield, S.E., Goodreau, S.M., Abernethy, N., Gottlieb, G.S., Mittler,

510 J.E. and Herbeck, J.T., 2019. Models to predict the public health impact of vaccine resistance: A

511 systematic review. Vaccine, 37(35), pp.4886-4895.

512 Roberts, M.G. and Heesterbeek, J.A.P., 2003. Mathematical models in epidemiology (Vol. 215).

513 EOLSS.

514 Roche, B., Drake, J.M. and Rohani, P., 2011. An Agent-Based Model to study the epidemiological

515 and evolutionary dynamics of Influenza viruses. BMC bioinformatics, 12(1), pp.1-10.

516 Rochman, N.D., Wolf, Y.I., Faure, G., Mutz, P., Zhang, F. and Koonin, E.V., 2021. Ongoing global

517 and regional adaptive evolution of sars-cov-2. Proceedings of the National Academy of

518 Sciences, 118(29).

519 Scherer, A. and McLean, A., 2002. Mathematical models of vaccination. British Medical

520 Bulletin, 62(1), pp.187-199.

521 Taubenberger, J.K. and Kash, J.C., 2010. Influenza virus evolution, host adaptation, and

522 pandemic formation. Cell host \& microbe, 7(6), pp.440-451.

523 van Baalen, M. and Sabelis, M.W., 1995. The dynamics of multiple infection and the evolution

524 of virulence. The American Naturalist, 146(6), pp.881-910. 
medRxiv preprint doi: https://doi.org/10.1101/2021.08.19.21262307; this version posted August 24, 2021. The copyright holder for this preprint (which was not certified by peer review) is the author/funder, who has granted medRxiv a license to display the preprint in perpetuity. It is made available under a CC-BY-NC-ND 4.0 International license.

Evolution of virus

Bell

525 Wang, P., Nair, M.S., Liu, L., Iketani, S., Luo, Y., Guo, Y., Wang, M., Yu, J., Zhang, B., Kwong, P.D.

526 and Graham, B.S., 2021. Antibody resistance of SARS-CoV-2 variants B. 1.351 and B. 1.1.

527 7. Nature, 593(7857), pp.130-135.

528 Worby, C.J., Wallinga, J., Lipsitch, M. and Goldstein, E., 2017. Population effect of influenza

529 vaccination under co-circulation of non-vaccine variants and the case for a bivalent A/H3N2

530 vaccine component. Epidemics, 19, pp.74-82. 
0.35 medRxiv preprint doi: https://doi.org/10.1101/2021.08.19.21262307; this version posted August 24, 2021. The copyright holder for this preprint

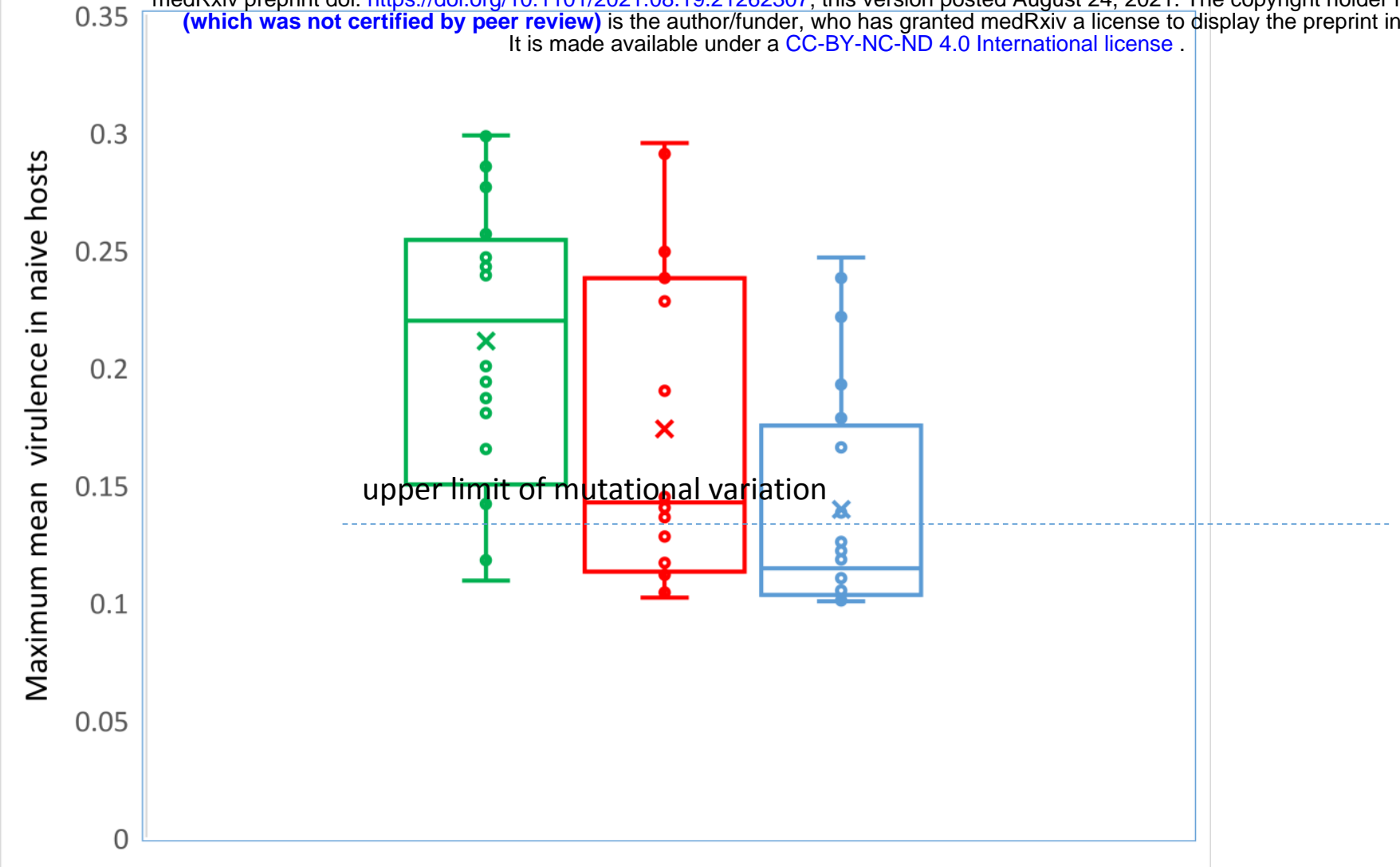

\section{1}

\section{Initial value}

542

543

Unvaccinated

Vaccinated

High efficacy

544

Vaccinated

Low efficacy

545

546 
medRxiv preprint doi: https://doi.org/10.1101/2021.08.19.21262307; this version posted August 24, 2021. The copyright holder for this preprint (which was not certified by peer review) is the author/funder, who has granted medRxiv a license to display the preprint in perpetuity. It is made available under a CC-BY-NC-ND 4.0 International license.

Evolution of virus

Bell

Figure 2

549

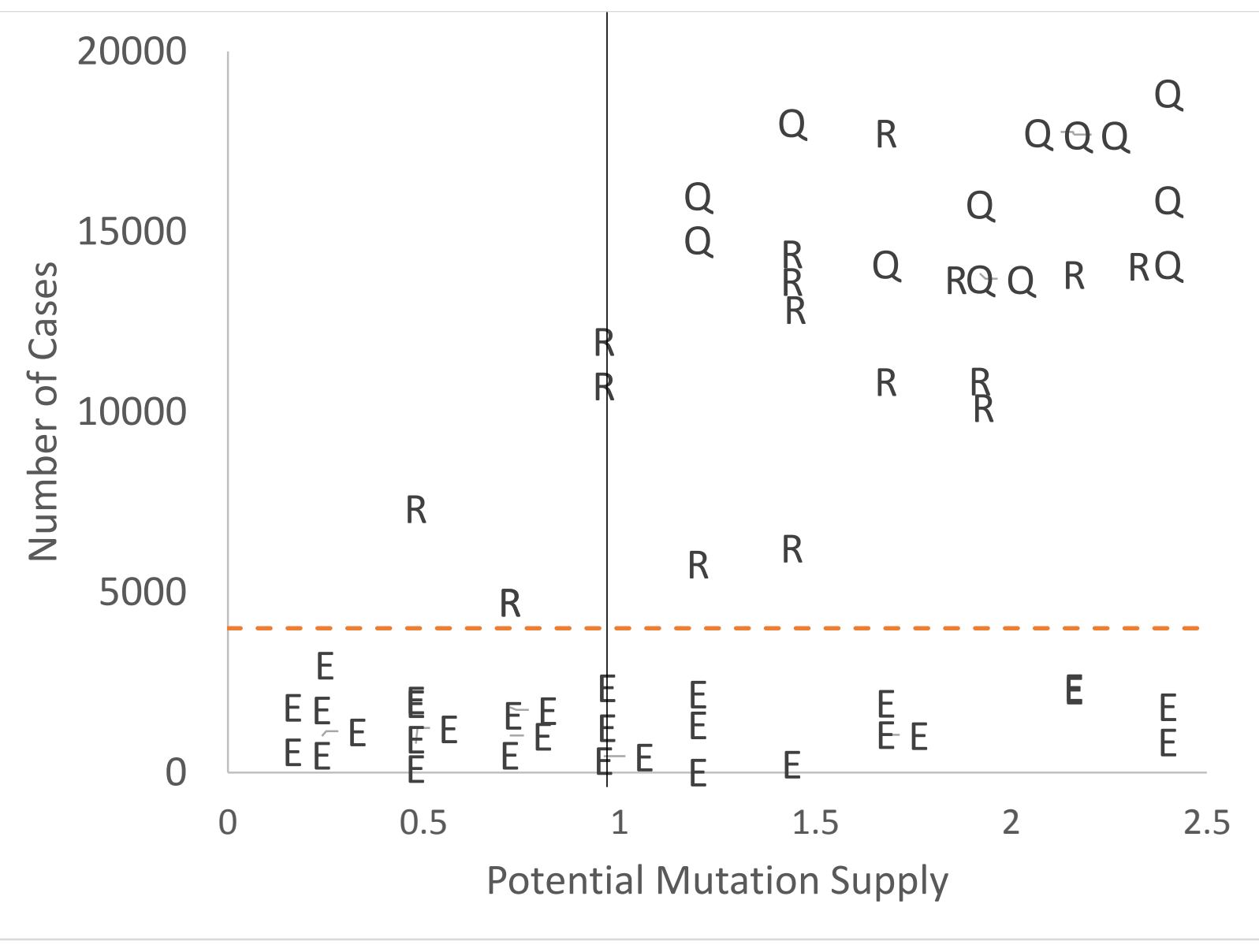

551

552 
medRxiv preprint doi: https://doi.org/10.1101/2021.08.19.21262307; this version posted August 24, 2021. The copyright holder for this preprint (which was not certified by peer review) is the author/funder, who has granted medRxiv a license to display the preprint in perpetuity. It is made available under a CC-BY-NC-ND 4.0 International license .

Evolution of virus

Bell

553

Figure 3

554

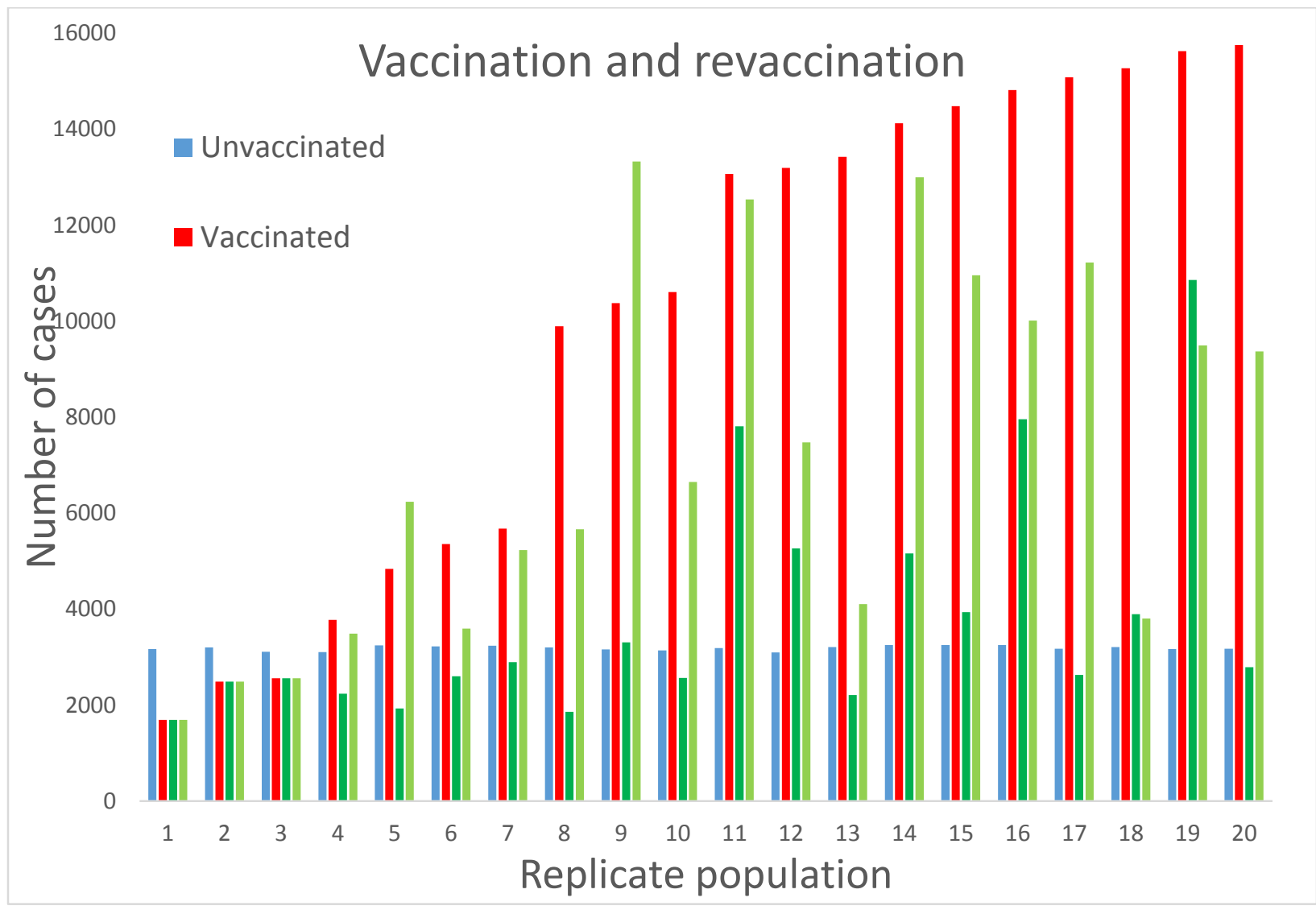

556

557 
medRxiv preprint doi: https://doi.org/10.1101/2021.08.19.21262307; this version posted August 24, 2021. The copyright holder for this preprint (which was not certified by peer review) is the author/funder, who has granted medRxiv a license to display the preprint in perpetuity.

\section{It is made available under a CC-BY-NC-ND 4.0 International license .}

Evolution of virus

Bell

Figure 4

559

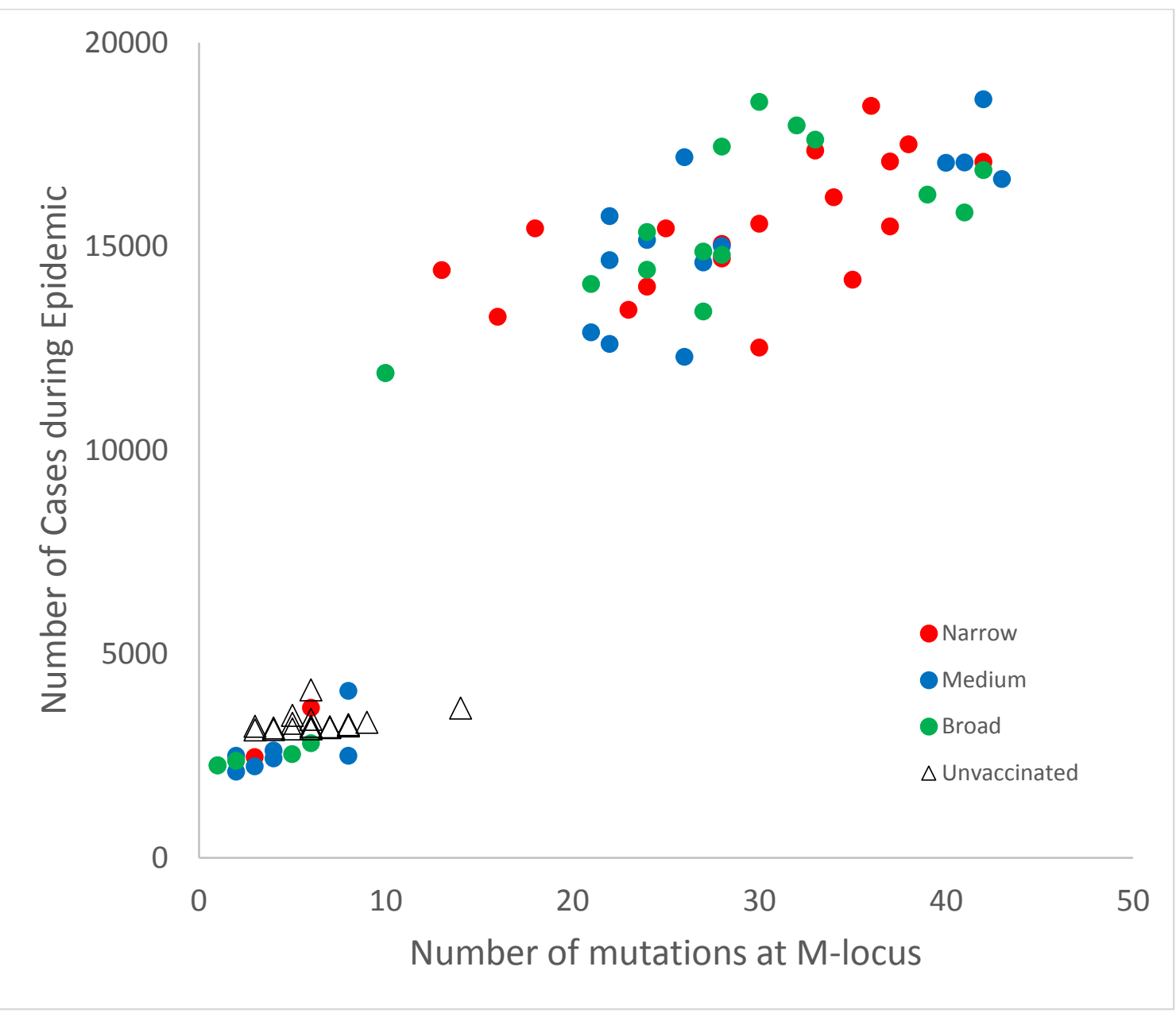

561

562 
medRxiv preprint doi: https://doi.org/10.1101/2021.08.19.21262307; this version posted August 24, 2021. The copyright holder for this preprint (which was not certified by peer review) is the author/funder, who has granted medRxiv a license to display the preprint in perpetuity. It is made available under a CC-BY-NC-ND 4.0 International license .

Evolution of virus

Bell

\section{Figure 5}

564

565

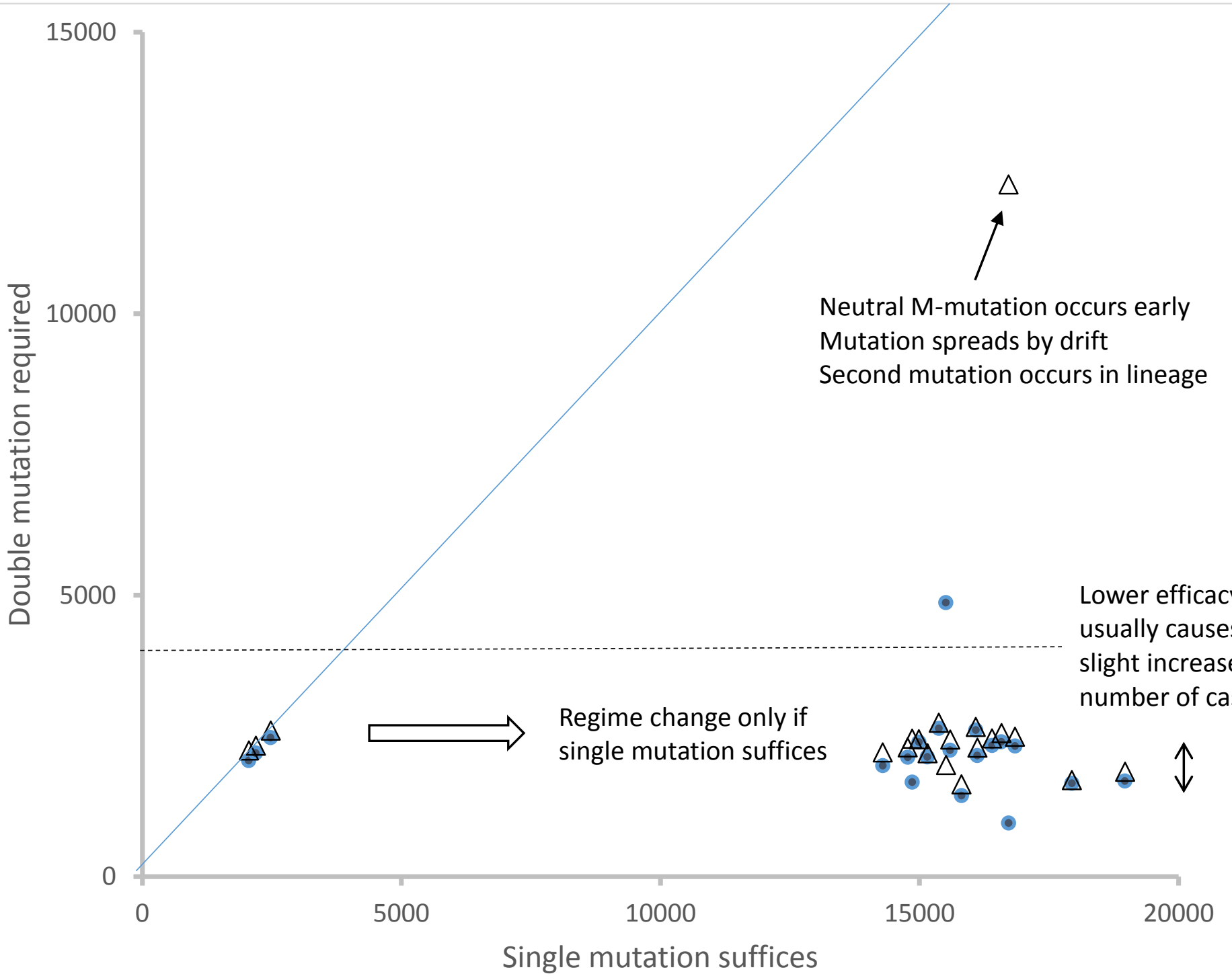


medRxiv preprint doi: https://doi.org/10.1101/2021.08.19.21262307; this version posted August 24, 2021. The copyright holder for this preprint (which was not certified by peer review) is the author/funder, who has granted medRxiv a license to display the preprint in perpetuity.

It is made available under a CC-BY-NC-ND 4.0 International license .

Evolution of virus

Bell

$588 \quad$ Figure 6

589

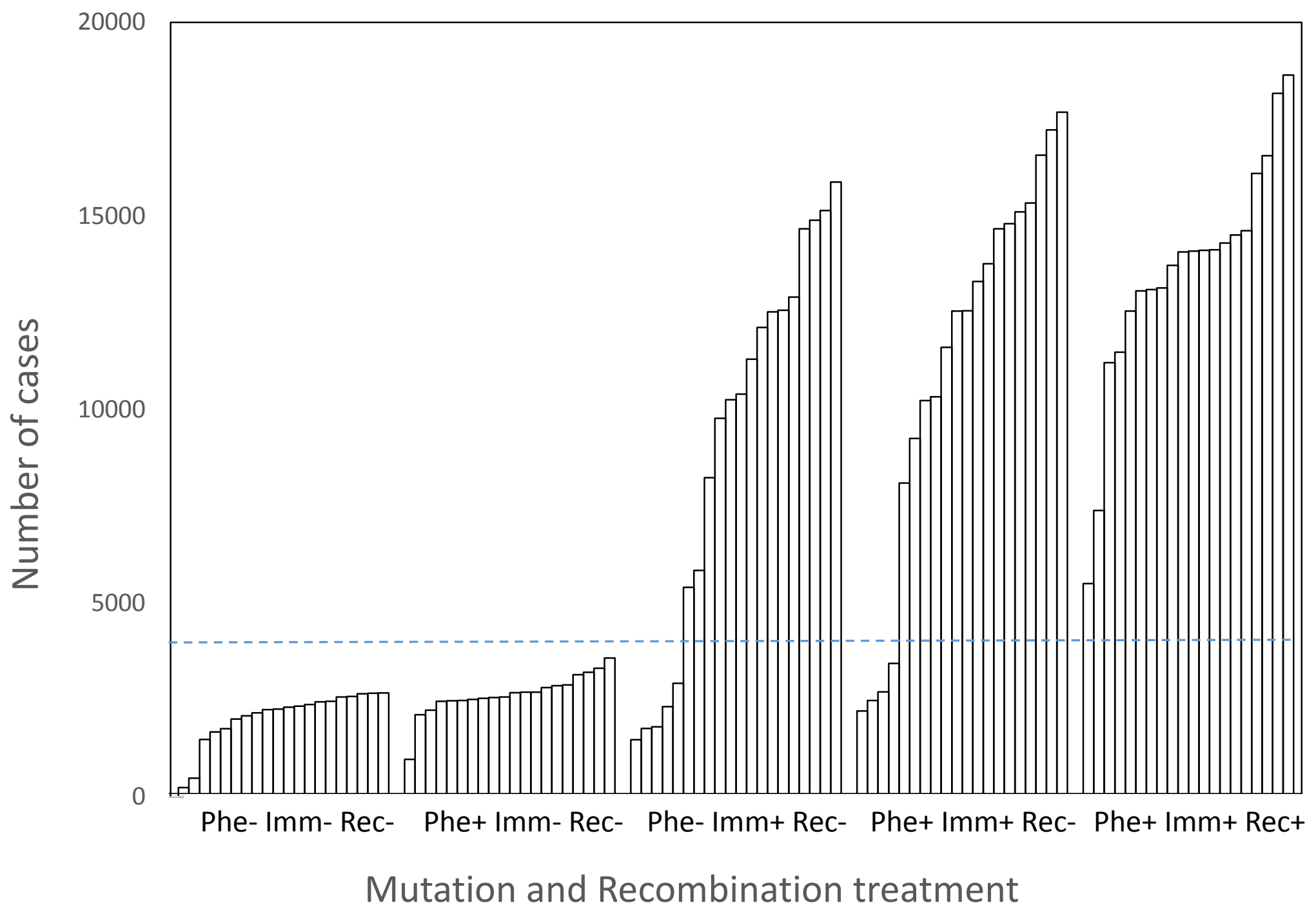

